\title{
THE EFFECT OF PEER TUTORING STRATEGY ON STUDENTS' READING COMPREHENSION IN NARRATIVE TEXT AT GRADE X SMA NEGERI 8 PADANGSIDIMPUAN
}

\author{
Aminah Adelini, Eka Sustri Harida, and Fitri Rayani Siregar \\ IAIN Padangsidimpuan \\ esha_stainpasid@yahoo.com, and syifaquinn@gmail.com
}

\begin{abstract}
Abstrak
Penelitian ini mengangkat masalah siswa dalam membaca di SMA Negeri 8 Padangsidimpuan, seperti mencari ide utama, topik, struktur teks, lemahnya penguasaan kosa kata. Untuk mengatasi masalah tersebut para peneliti sepakat untuk menggunakan strategi peer tutoring sehingga tujuan dari penelitian yang dilakukan adalah untuk menguji efektifitas strategi tersebut terhadap pemahaman siswa dalam membaca teks naratif di SMA Negeri 8 Padangsidimpuan. Para peneliti menggunakan metode penelitian dengan pendekatan kuantitatif dalam desain eksperimental untuk menguji hipotesis yang telah disampaikan pada awal penelitian. Sampel pada penelitian ini adalah 52 orang siswa kelas $X$ dengan 26 orang siswa sebagai kelas control dan 26 siswa sebagai kelas eksperimen. Tes yang digunakan adalah tes pilihan berganda, pengumpulan data dilakukan melalui pre-tes, post-test dan treatment, sementara analisis data dengan menggunakan uji-t. dari penelitian yang dilakukan diketahui bahwa nilai rata-rata kelas control lebih kecil dari pada kelas eksperimen $(75.76<82.12)$, dan hasil uji-t lebih besar dari pada $t-$ table $((2.28>2.021))$, sehingga jatuh pada kesimpulan bahwa hipotesis diterima, yakni terdapat pengaruh yang signifikan penggunaan strategi peer tutoring terhadap kemampuan membaca teks naratif siswa kelas X SMA Negeri Padangsidimpuan.
\end{abstract}

Kata Kunci: Strategi Peer Tutoring, Membaca Pemahaman, dan Teks Naratif

\begin{abstract}
This research discussed about students' problems in reading comprehension at grade X SMA Negeri 8 Padangsidimpuan, such as got difficult to recognize main idea, topic, and the generic structure of some text types, lack of vocabularies related to the topic of the text that would be read. As the result, the students are difficult in reading comprehension. The aim of this research is to find out the effect of peer tutoring strategy on students' reading comprehension at grade X SMA Negeri 8 Padangsidimpuan, by quantitative approach using experimental method. Experimental method is used to test hypotheses and to see the effect of peer tutoring strategy on students' reading comprehension at grade X SMA Negeri 8 Padangsidimpuan. The resource of the data was cluster sampling, there were 52 students from 105 students of grade X SMA Negeri 8 Padangsidimpuan. Collecting the data researcher was
\end{abstract}


done the instrument test for the students about reading comprehension. To analysis the data, the researcher used formulation of t-test. Based on the result of the research, researcher showed the description of the data was found that the mean score in post-test of experimental class higher than control class $(82.12>75.76)$ and the score of to was bigger than $t_{t}(2.28>2.021)$. It means that the hypothesis was accepted. It was concluded that there was the effect of peer tutoring strategy on Students' reading comprehension at grade X SMA Negeri 8 Padangsidimpuan. Finally, the researcher suggested using peer tutoring strategy was effective to increase students' reading comprehension.

Keywords: Peer Tutoring Strategy, Reading Comprehension, Narrative Text

\section{INTRODUCTION}

Reading is important skill in teaching learning. By reading it can be a key to achieve the goal of teaching learning especially in English language learning. Reading is an activity to get information. Who is read, he/she can get much knowing and don't leave information.

Reading is not an ordinary activity in which readers just read a text, but it refers to a greater coverage instead. Certainly, it is how they interpret what writers mean appropriately since different texts will refer to different purposes and functions. Reading is an essential skill for learners of English as a second language. For most of these learners it is one of important skill to master in order to ensure success is not only in learning English, but also in learning in any content class where reading in English is required. With strengthened reading skills, learners will make greater progress and development in all other areas of learning.

Riska Juliati as a teacher at SMA Negeri 8 Padangsidimpuan said the students reading competence was still low. ${ }^{1}$ The students got difficult to recognize main idea, topic, and the generic structure of some text types. Also the students still lack of vocabularies related to the topic of the text that would be read.

The next, Muhammad Ferdiansyah Putra as student at SMA Negeri 8 Padangsidimpuan said the students are uninterested in learning reading, because the strategy used teacher in teaching is monotonous. ${ }^{2}$ These facts could be clearly

${ }^{1}$ Riska Juliati Sihombing as a teacher at SMA Negeri 8 Padangsidimpuan, Private Interview on January $30^{\text {th }} 2017$ at 11.00 a.m.

${ }^{2}$ Muhammad Ferdiansyah Putra as student of SMA Negeri 8 Padangsidimpuan, Private Interview on February $06^{\text {th }} 2017$ at 12.30 p.m. 
seen from the students have bad attitudes, example most of the students kept noisy and shamelessly ignored the teacher explaining in front. The students indeed needed something different from the teacher. It could be a new teaching strategy else to support and raise their motivation.

The last, Nursyaidah as a student also said the teacher in the class only use speech strategy in teaching and it is a boring strategy. ${ }^{3}$ Besides, the teacher often asks the student to read but the teacher doesn't teach a way to read it. In addition, the teacher only reference followed was the instruction printed in the module without making side activity or improvisation. Certainly, a good teacher should have creativity and good competence. That is why the teacher should find a new brand way to get the students interested and motivated.

Seeing problem above, the researcher finds that the English teacher still need other strategy to make students interest to teaching reading. Reading strategy is very much such as previewing strategy, contextualizing strategy, questioning strategy, outlining strategy, summarizing strategy, and peer tutoring strategy. In this case, the researcher wants to be introduced peer tutoring as a strategy.

Peer tutoring is a student is given task by teacher to help other students have difficulty in study. Greenwood stated that class-wide peer tutoring is an instructional strategy developed to help teachers individualize instruction, while still providing students with ample opportunity to become actively engaged during instruction". Seemingly, he considers that there is no distinctive thing between class-wide peer tutoring and peer tutoring. ${ }^{4}$ Paul states that peer tutoring is helpful for students in reading, spelling, mathematic, and writing. ${ }^{5}$ Students have more opportunities to give questions when they are still confused, without afraid to embarrassed in front of the class. In peer tutoring someone who can correct or support them related to their answers are true or not true and someone can help and encourage them to finish assignments. So, peer tutoring strategy is the strategy can help students in the study reading.

${ }^{3}$ Nursyaidah as a student of SMA Negeri 8 Padangsidimpuan, Private Interview on February $06^{\text {th }} 2017$ at 12.40 p.m.

${ }^{4}$ Charles Greenwood, "Classwide Peer Tutoring.," Behavior and Social Issues 7, no. 1 (1997): 53-57, https://doi.org/http://dx.doi.org/10.5210/bsi.v7i1.299.

${ }^{5}$ G.J. Du Paul, Peer Tutoring Procedures in General Education Classrooms. In A.S. Canter E S. A. Carroll (Eds.), Helping Children at home and school: Handouts from Your School Psychologist. National Association of School Psychologists, Bethesda: MD.1998, p. 1. 
So, the aim of this study is to examine the effectiveness of using peer tutoring strategy to students' reading comprehension in narrative text at Grade $X$ SMA Negeri 8 Padangsidimpuan.

\section{THEORITICAL DESCRIPTION}

\section{Peer Tutoring}

Peer means friend in the same age level while tutoring means private teacher. Peer tutoring strategy is private teacher in the same age level give instruction and assist in study. Peer tutoring is an instructional strategy that consist of student partnerships, linking high achieving students with lower achieving students or those with comparable achievement, for structured reading and math study sessions. ${ }^{6}$ Peter also said that peer tutoring is a type of collaborative learning strategy in which students support each other's learning rather than relying solely on an adult teacher. ${ }^{7}$ So, peer tutoring is one of collaborative learning strategy which smart students as a private teacher for lower achieving students.

Peer tutoring has been well validated for promoting the development of low-level skills, such as spelling, math and reading. ${ }^{8}$ Peer tutoring also has been used with college students to develop higher-order skills such as reading comprehension. ${ }^{9}$ Nancy said peer tutoring involved children acting as surrogate teachers whose aim was the transmission of knowledge. ${ }^{10}$ In contrast, more modern conceptions of peer tutoring involve 'people from similar social groupings who are not professional teachers helping each other to learn and learning themselves by teaching'.

${ }^{6}$ Joan walker, Using Peer Tutoring to Facilitate Accessed, accessed from http://wee jeelearning.com/portfoliofiles/hill_center_di/assets/resources/PeerTutoring.pdf. Retrieved on $19^{\text {th }}$ April 2017.

7Peter, Mentoring and Tutoring, accessed from http://www.unicommons.com/node/6975. Retrieved on $19^{\text {th }}$ April 2017.

${ }^{8} \mathrm{~L} S$ Fuchs et al., "Acquisition and Transfer Effects of Classwide Peer-Assisted Learning Strategies in Mathematics for Students with Varying Learning Histories," SCHOOL PSYCHOLOGY REVIEW 24, no. 4 (1995): 604-20, https://doi.org/Article.

${ }^{9}$ D. F. Dansereau, Transfer from cooperative to individual studying. Journal of Reading, (5),1987, p. 614-619, assessed from goo.gl/uZUilo, retrieved on $20^{\text {th }}$ December 2017 at 08.30 a.m.

10 Nancy Falchikov and Judy Goldfinch, "Student \{Peer\} \{Assessment\} in \{Higher\} \{Education\}: $\{\mathrm{A}\}$ \{Meta\}-\{Analysis\} \{Comparing\} \{Peer\} and \{Teacher\} \{Marks\}," Review of Educational Research 70, no. 3 (2000): 287-322, http://www.jstor.org/stable/1170785. 


\section{The Procedures of Peer Tutoring}

Teaching is the process of attending to people's needs, experiences and feelings, and making specific interventions to help them learn particular things. Strategy is someone manner to get goals. Teaching strategy of peer tutoring is manner to doing teaching with using peer tutoring as the strategy. Teaching strategy of peer tutoring, are:

1) Students take turns being the tutor and the tutee. Students who participate in the strategy are ranked from highest to lowest reading achievement. The first student on the "high" half of the list is paired with the first student on the "low" list.

2) During the session, the students practice using three specific reading strategies for comprehension. First, students will read a text and then practice retelling what they just read. The higher-level student always goes first to demonstrate what to look for in the text. The lower level student then goes next with the same set of reading material. Second, pairs work on paragraph shrinking. The pairs practice reading a single paragraph, and then they work to identify the main points. They have to look for the most important piece of information that was present in this one paragraph. The last strategy is prediction relay. This involves the students predicting what a text is going to be about based on the title. After they read the passage, they then get to evaluate their original prediction and discuss whether or not they were correct. They then switch roles and the other student gets to try prediction relay with new material.

3) Students are taught to correct their partners' errors, award points for being correct and provide consistent praise and feedback. ${ }^{11}$

\section{Lecture Strategy}

Lecture Strategy is traditional strategy because this strategy had been used long since is as an oral communication tool between teacher and students in interaction educative. Moreover, in educative and traditional teaching it is like in

\footnotetext{
${ }^{11}$ Topping, The peer tutoring handbook: Promoting cooperative learning, accessed fromhttps://www.oakland.edu/Assets/upload/docs/WRT/Peer_Tutoring_in_Reading_Comprehension.pdf. Retrieved on $11^{\text {th }}$ Mei 2017.
} 
rural that have weakness in learning facilities and teacher. ${ }^{12}$ So, lecture strategy is strategy which is conducted by the teacher to teach the material to students based on mutual agreement in a school.

There are some steps of lecture strategy, they are:

1 Preparation (creates the learning condition to students)

2 Implementation (conveys the material then given opportunity to students for connecting and comparing the material of lecturer that had accepted through catechizing)

3 Evaluation (gives a test to students for looking students' comprehension about material that had learned).$^{13}$

The lecturer strategy is the strategy that usually used by mostly teachers in teaching English, especially in reading. Although it can be said as conventional strategy, but most teachers like to use it, and it is also in good planning because have preparation, implementation, and also evaluation.

\section{Reading Comprehension}

Basically, reading and comprehension cannot be separated. Because, reader in read text must be comprehend to get more information. Reading comprehension is the process of making sense of text, a complex, multifaceted activity that calls on the reader's thinking and problem-solving skills.

Reading comprehension is the ability to understand information presented in written form. Reading comprehension is mental process in which the readers try to understand the meaning in the text by interpreting what have been read in order to find the new idea that given by the writers. Wainwright stated reading comprehension as a complex process which is taking part of useful of good and poor ability. ${ }^{14}$ In other word, reading comprehension is ability of the reader to understand the text and comprehend the mean of the text.

Goodman in Wayne Otto stated that reading comprehension is interaction between thought and language and bases evaluation of success in comprehension on the extent to which the reader's reconstructed message agrees

${ }^{12}$ Syaiful Bahri Djamarah, Guru dan Anak Didik (dalam Interaksi Edukatif), (Jakarta: PT. Rineka Cipta, 2000), p. 205.

${ }^{13}$ Syaiful Bahri Djamarah, Guru dan Anak Didik..... p.99.

${ }^{14}$ Golden Wainwright, Speed Reading Better Recalling , (Jakarta: Gramedia, 2007), p.42. 
with the writer's intend message. ${ }^{15}$ Next, Tarigan gave the definition of reading comprehension it is reading activity that interpreting the experience in connecting new information with the prior knowledge, and also to answer the cognitive questions. ${ }^{16}$

\section{Narrative Text}

Narrative text is the imaginative story to entertain the people. Narrative text is an imaginative story to entertaining or amusing the readers. ${ }^{17}$ Narrative text is a story with complication or problematic events and it tries to find the resolutions to solve the problems. ${ }^{18}$ An important part of narrative text is the narrative mode, the set of methods used to communicate the narrative through a process narration. The Purpose of Narrative Text is to amuse or to entertain the reader with a story.

Generic structure of narrative text, are:

1) Orientation

This part is commonly mentioned in the first paragraph, it can be called as an introductory part of a story. The narrator let the readers know where and when the story takes place and who are involved in the story called as characters. Every event must be supported by some characters which participated in a story. Characters regard as a particular role in a story. The characters mention such as beautiful, helpful, selfish, faithful, etc. In the part of orientation, students could mention not only adjectives which belongs to the characters but also physical characteristic such as; weight, age, height and so forth.

2) Complication

In this part, the narrator tells us about something that will begin in a series of event. This event will influence toward one or some characters. The complication is a trigger.

${ }^{15}$ Wayne Otto, How to Teach Reading, (America: Addisen Wesley Publishing, 1979), p. 161.

16 Henry Guntur Tarigan, Membaca Sebagai Keterampilan Berbahasa, (Bandung: Aksara, 1990), p.7.

17Joko Priyana, dkk, Be smart in English for Grade X of Senior High Schools, (Jakarta, Grasindo: 2008), p. 50.

18 Aris munan, Developing English Competencies, accessed from http://duoulala.blogspot .co.id/2013/07/narrative-text-definition-purposes.html. Retrieved on $22^{\text {th }}$ September 2017. 
198 | TAZKIR: Jurnal Penelitian Ilmu-ilmu Sosial dan Keislaman

Vol. 04 No. 1 Juni 2018

3) Resolution

This part can be found in the end of the story. The narrator finishes the story by giving readers and listener about a problem solving of complication or the complication is sorted out.

4) Coda

The narrator will put together a coda in the text if there is a moral value or message from the story which could become as learning for both the readers and listeners. ${ }^{19}$

Language features of narrative text are focus on specific or individual participants, using of past tense and using of temporal conjunction and temporal circumstances, ex: the, after, that, once upon a time, etc.

\section{RESEARCH METHODOLOGY}

This research was done at SMA Negeri 8 Padangsidimpuan. It was located on Jl. Perkebunan Pijorkoling Kec. Padangsidimpuan Tenggara, Pulau Bauk village. The process of this research was from 02 December 2016 - 21 December 2017. This research is conducted quantitative method by using experimental design; pre-test, treatment, and post-test were used in research in experimental class, while in control class used pre-test and post-test. Population of the research are all of student grade X SMA Negeri 8 Padangsidimpuan and sample of the research are students grade X MIA-1 and X MIA-2 consisted of 52 students, 26 students for each group. Data of this research are collected by using instrument. The instrument of collecting data was test. The data analyzed by using T-test.

\section{RESEARCH RESULT AND DISCUSSION}

Result of Pre-test

To evaluate the effect of peer tutoring strategy to students' reading comprehension in narrative text at grade X SMA Negeri 8 Padangsidimpuan, researcher has calculated the data by pre-test and post-test. Based on researcher was done, researcher got the result of data pre-test of students' score in experimental class and control class. The result of pre-test in experimental class with sample 26 students was got by total of score was 1840, mean was 70.74,

${ }^{19}$ Mark and Kathy Anderson, Text Types in English 3, Sydney: McMillan, 1997, p. 4. 
median was 81.3 , modus was 61.5 , range was 35 , interval was 6 , standard deviation was 27.66, and variant was -74.61 . The researcher got the highest score was 85 and the lowest score was 50. The result of pre-test in control class with sample 26 students was got b total of score was 1855, mean was 73.34, standard deviation was 18.5 , variant was 97.12 , range was 30 , interval was 5 , median was 82 and modus was 69.5. Researcher got the highest score was 85 and the lowest score was 55.

Result of Post-Test

The result of post-test in experimental class with sample 26 students was got by total of score was 2135 , mean was 82.12 , standard deviation was 23.87 , variant was 101.34 , median was 91 , range was 40 , modus was 71.17 , and interval was 7. The students' highest score was 100 and the lowest score was 60 . The result of post-test in control class with sample 26 students was got by total of score was 1980, mean was 75.76, standard deviation was 22.54, variant was 120.61, median was 77.46, range was 40, modus was 72, and interval was 7 . Researcher got the highest score was 95 and the lowest score was 55 .

\section{Testing Hypothesis}

After calculating the data of post-test, researcher has found that post-test result of experimental and control class is normal and homogenous. The data would be analyzed to prove the hypothesis. It used formula of $t$-test. Hypothesis of the research was "peer tutoring has significant effect on students' reading comprehension in narrative text at grade X of SMA Negeri 8 Padangsidimpuan". The result of t-test was as follow:

Table I

$$
\text { Result of T-test }
$$

from the Both Averages

\begin{tabular}{llll}
\hline Pre-test & \multicolumn{3}{c}{ Post-test } \\
\hline$t_{\text {count }}$ & $t_{\text {table }}$ & $t_{\text {count }}$ & $t_{\text {table }}$ \\
\hline-2.92 & 2.021 & 2.28 & 2.021 \\
\hline
\end{tabular}

The test hypothesis have two criteria. First, if $t_{\text {count }}<t_{\text {table, }}, H_{0}$ is accepted. Second, $t_{\text {count }}>t_{\text {table }}, H_{a}$ is accepted. Based on researcher calculation in pre test, researcher found that $t_{\text {count }}-2.92$ while table 2.021 with opportunity $(1-\alpha)=1-5 \%$ 
200 | TAZKIR: Jurnal Penelitian Ilmu-ilmu Sosial dan Keislaman

Vol. 04 No. 1 Juni 2018

$=95 \%$ and $d k=n_{1}+n_{2}-2=26+26-2=50$. Cause $t_{\text {count }}<t_{\text {table }}(-0.29<2.021)$, it means that hypothesis $\mathrm{H}_{a}$ was rejected and $\mathrm{H}_{0}$ was accepted. So, in pre test, the two classes were same. There is no difference in the both classes. But, in post test, researcher found that $t_{\text {count }} 2.28$ while table 2.021 with opportunity $(1-\alpha)=1-5 \%=$ $95 \%$ and $d k=n_{1}+n_{2}-2=26+26-2=50$. Cause $t_{\text {count }}>t_{\text {table }}(2.28>2.021)$, it means that hypothesis $\mathrm{H}_{a}$ was accepted and $\mathrm{H}_{0}$ was rejected. In this case, the mean score of experimental class by using peer tutoring strategy was 82.12 and mean score of control class was 75.76 that was taught by using lecturer strategy. So, there was the significant effect of using peer tutoring strategy on students' reading comprehension in narrative text at grade X SMA Negeri 8 Padangsidimpuan.

\section{DISCUSSION}

Researcher discussed result of this research and compared with the theory and the related findings that have been stated by the researcher. Firstly, related to the theory from Densereau stated that Peer tutoring has been used with college students to develop higher-order skills such as reading comprehension. ${ }^{20}$ Based on it, it is known that using techniques, strategy, or methods can be used to teach reading, as stated by Harida ${ }^{21}$, Chen ${ }^{22}$, and $\mathrm{Ahmad}^{23}$. They agreed that reading comprehension improved by many kinds, such as techniques, techniques, methods, or even medias. This is the improvement of the students' reading comprehension by using such kinds of methods, medias, or techniques.

Not only for reading strategies and techniques are good, but also for learning vocabulary, as stated by Harida ${ }^{24}, \mathrm{Utami}^{25}$, and Munir ${ }^{26}$. They found that

${ }^{20} \mathrm{D}$. F. Dansereau, Transfer from cooperative to individual studying. Journal of Reading, (5),1987, p. 614-619, assessed from goo.gl/uZUilo, retrieved on $20^{\text {th }}$ December 2017 at 08.30 a.m.

${ }^{21} E k a$ Sustri Harida, “USing Critical Reading Strategies: One Way for Assessing Students' Reading Comprehension," ISELT-4, 2016, 199-206, https://goo.gl/a3zyri.

${ }^{22}$ Chin Neng Chen et al., "The Effects of Extensive Reading via E-Books on Tertiary Level EFL Students' Reading Attitude, Reading Comprehension and Vocabulary," Turkish Online Journal of Educational Technology 12, no. 2 (2013): 303-12.

${ }^{23}$ Ahmad Suri, "The Effect of Context Clues in Reading Comprehension of the Eleventh Grade Students at SMA Negeri 3 Palangkaraya" (2015), http://digilib.iain-palangkaraya.ac.id/204/.

${ }^{24}$ Eka Sustri Harida, "Using Mind Mapping Technique to Teach Vocabulary" 3, no. 1 (2015): 10, http://repo.iain-padangsidimpuan.ac.id/176/1/1. Eka -min.pdf.

${ }^{25}$ Yheni Siwi Utami, "IMPROVING STUDENTS' VOCABULARY MASTERY USING CROSSWORD PUZZLES FOR GRADE VII OF SMP N 2 SRANDAKAN IN THE ACADEMIC YEAR OF 2013/2014," Yogyakarta State University (2014), https://doi.org/10.1017/CBO9781107415324.004. 
vocabulary learning is good and improved by using mind mapping, crossword, and films. As known that vocabulary is important for learning many skills in English; it is also for reading comprehension. Lailatul ${ }^{27}$ and Sumantri ${ }^{28}$ stated that vocabulary mastery has relationship to reading comprehension. So, it is stated that vocab is important in reading.

What have been stated above is related to the topic of this research, meanwhile more explanation what is significantly related to peer tutoring and reading. Fuchs ${ }^{29}$ said the peer tutoring strategy has been well validated for promoting the development of low-level skills, such as spelling, math and reading. Then, Grunkie and Leidig said that teaching by peers (peer tutoring) and story mapping was more effective than teaching by teachers, this is due to the background of the student experience that is similar to one another than with the schemata teachers ${ }^{30}$. It means that learning process does not have come from the teacher to students, but can also from students to other students.

Then, Dika Prima Nugraha Putra also has done research. ${ }^{31}$ The result of the research had shown that Peer Tutoring could be an effective technique to improve the students' reading comprehension. This conclusion came from the analysis of the test result. He found that students' scores mean of the pre-test was 47.26, whose the highest and lowest score in turn were 70, and 35, in the post-test having mean score was 77.41 and having 85 as the biggest, and 55 as the smallest score.

${ }^{26}$ Fathul Munir, "The Effectiveness of Teaching Vocabulary by Using Cartoon Film toward Vocabulary Mastery of EFL Students," Journal of English Language Teaching and Linguistics 1, no. 1 (2016): 13-37, https://doi.org/http://dx.doi.org/10.21462/jeltl.v 1 i 1.20.

${ }^{27}$ Latifatul Hidayati and Bambang Eko Siagiyanto, "The Correlation between Vocabulary Mastery and Reading Comprehension Achievement," PREMISE: Journal of English Education 1, no. 1 (2012): 1-5, http://fkip.ummetro.ac.id/journal/index.php/english/article/view/1109/785.

28 Mohamad Syarif Sumantri, Nurjannah, and Yubaedi Siron, "The Impact of Metacognition and Vocabulary Mastery on Reading Comprehension in Elementary Student: A Path Analysis," Advanced Science Letters 23, no. 1 (2017): 537-39, https://doi.org/10.1166/asl.2017.7248.

${ }^{29}$ Fuchs et al., "Acquisition and Transfer Effects of Classwide Peer-Assisted Learning Strategies in Mathematics for Students with Varying Learning Histories."

${ }^{30}$ Matthias Grünke and Tatjana Leidig, "The Effects of an Intervention Combining Peer Tutoring With Story Mapping on the Text Comprehension of Struggling Readers: A Case Report," Educational Research Quarterly 41, no. 1 (2017): 41-60.

${ }^{31}$ Dika Prima Nugraha Putra, Improving Grade XI Students' Reading Comprehension by Using Peer Tutoring at SMA N 1 Pleret, 2013, accessed from http//:eprints.umk.ac.id/1173/1/ TITLE.pdf. Retrieved on $20^{\text {th }} 2017$ at 08.20 a.m 
The last, Besty Maghfiroh has also done research. ${ }^{32}$ The result of the research had shown that Peer Tutoring could be an effective method to increase the students' interest and matematika study result. This conclusion came from the analysis of the test result. He found that students' scores mean of the pre-test was 61.83, in the post-test having mean score was 77.30.

The research result and the theory have proven that this strategy is good where the students were so enthusiastic to follow the lesson. This proofs show that peer tutoringis suitable to be applied in teaching reading comprehension. So, peer tutoring strategy has given the effect to the research that has been done by the researcher or the other researcher who mentioned in related findings.

\section{CONCLUSION}

Based on result of research, the conclusions of this research are:

1. The students' reading comprehension in narrative text before using peer tutoring strategy at grade X SMA Negeri 8 Padangsidimpuan was still low, it can be seen from the mean score of experimental class was 69.54 were under standardization where the standardization mark is 80 .

2. The students' reading comprehension in narrative text after using peer tutoring strategy was increasing, in can be seen from the mean score of experimental class was higher than before using peer tutoring strategy. The mean score of post-test for experimental class was 82.57 where it was upper standardization.

3. Based on researcher calculation, researcher found that $t_{\text {count }} 2.28$ while table 2.021 with opportunity $(1-\alpha)=1-5 \%=95 \%$ and $d k=n_{1}+n_{2}-2=26+26-2=$ 50. Cause $t_{\text {count }}>t_{\text {table }}(2.28>2.021)$, it means that hypothesis $\mathrm{H}_{a}$ was accepted and $\mathrm{H}_{0}$ was rejected. It means that there was a significant effect of peer tutoring strategy on students' reading comprehension in narrative text at grade $\mathrm{X}$ of SMA Negeri 8 Padangsidimpuan.

${ }^{32}$ Besty Maghfiroh, Pengaruh Strategi Pembelajaran Kooperatif Model Tutor Sebaya (Peer Tutoring) Terhadap Minat dan Hasil Belajar Matematika Kelas V Madrasah Ibtidaiyah Darul Huda Ngaglik Bandulan Sleman Yogyakarta, 2012, accessed from http://digilib.uin-suka.ac.id/9948/ $1 / B A B \% 20 I \% 2 C \% 20 I V \% 2 C \% 20 D A F T A R \% 20 P U S T A K A . p d f$. Retrieved on $20^{\text {th }} 2017$ at 08.25 a.m. 


\section{REFERENCES}

Ahmad Suri. "The Effect of Context Clues in Reading Comprehension of the Eleventh Grade Students at SMA Negeri 3 Palangkaraya," 2015. http://digilib.iain-palangkaraya.ac.id/204/.

Aris munan, Developing English Competencies, accessed from http://duoulala.blogspot.co.id/2013/07/narrative-text-definitionpurposes.html. Retrieved on $22^{\text {th }}$ September 2017.

Dansereau, D. F. Transfer from cooperative to individual studying. Journal of Reading, (5),1987, p. 614-619, assessed from goo.gl/uZUilo, retrieved on $20^{\text {th }}$ December 2017 at 08.30 a.m.

Du Paul, G.J. Peer Tutoring Procedures in General Education Classrooms. In A.S. Canter $\mathcal{E}$ S. A. Carroll (Eds.), Helping Children at home and school: Handouts from Your School Psychologist. National Association of School Psychologists, Bethesda: MD.1998.

Chen, Chin Neng, Shu Chu Chen, Shu Hui Eileen Chen, and Shyh Chyi Wey. "The Effects of Extensive Reading via E-Books on Tertiary Level EFL Students' Reading Attitude, Reading Comprehension and Vocabulary." Turkish Online Journal of Educational Technology 12, no. 2 (2013): 303-12.

Falchikov, Nancy, and Judy Goldfinch. “Student $\{$ Peer $\{$ Assessment $\}$ in $\{$ Higher\} \{Education\}: \{A\} \{Meta\}-\{Analysis\} \{Comparing\} \{Peer\} and \{Teacher\} \{Marks\}." Review of Educational Research 70, no. 3 (2000): 287-322. http://www.jstor.org/stable/1170785.

Fuchs, L S, D Fuchs, N B Phillips, C L Hamlett, and K Karns. “Acquisition and Transfer Effects of Classwide Peer-Assisted Learning Strategies in Mathematics for Students with Varying Learning Histories." SCHOOL PSYCHOLOGY REVIEW 24, no. 4 (1995): 604-20. https://doi.org/Article.

Greenwood, Charles. "Classwide Peer Tutoring." Behavior and Social Issues 7, no. 1 (1997): 53-57. https://doi.org/http://dx.doi.org/10.5210/bsi.v7i1.299.

Grünke, Matthias, and Tatjana Leidig. "The Effects of an Intervention Combining Peer Tutoring With Story Mapping on the Text Comprehension of Struggling Readers: A Case Report." Educational Research Quarterly 41, no. 1 (2017): 41-60.

Harida, Eka Sustri. “USing Critical Reading Strategies: One Way for Assessing 
204 | TAZKIR: Jurnal Penelitian Ilmu-ilmu Sosial dan Keislaman

Vol. 04 No. 1 Juni 2018

Students' Reading Comprehension." ISELT-4, 2016, 199-206. https://goo.gl/a3zyri.

- - - "Using Mind Mapping Technique to Teach Vocabulary" 3, no. 1 (2015): 10. http://repo.iain-padangsidimpuan.ac.id/176/1/1. Eka -min.pdf.

Henry Guntur Tarigan, Membaca Sebagai Keterampilan Berbahasa, (Bandung: Aksara, 1990).

Hidayati, Latifatul, and Bambang Eko Siagiyanto. "The Correlation between Vocabulary Mastery and Reading Comprehension Achievement." PREMISE: Journal of English Education 1, no. 1 (2012): 1-5. http://fkip.ummetro.ac.id/journal/index.php/english/article/view/1109/785.

Munir, Fathul. "The Effectiveness of Teaching Vocabulary by Using Cartoon Film toward Vocabulary Mastery of EFL Students." Journal of English Language Teaching and Linguistics 1, no. 1 (2016): 13-37. https://doi.org/http://dx.doi.org/10.21462/jeltl.v li 1.20.

Otto, Wayne. How to Teach Reading, (America: Addisen Wesley Publishing, 1979).

Sumantri, Mohamad Syarif, Nurjannah, and Yubaedi Siron. "The Impact of Metacognition and Vocabulary Mastery on Reading Comprehension in Elementary Student: A Path Analysis." Advanced Science Letters 23, no. 1 (2017): 537-39. https://doi.org/10.1166/asl.2017.7248.

Syaiful Bahri Djamarah, Guru dan Anak Didik (dalam Interaksi Edukatif), (Jakarta: PT. Rineka Cipta, 2000).

Utami, Yheni Siwi. “IMPROVING STUDENTS' VOCABULARY MASTERY USING CROSSWORD PUZZLES FOR GRADE VII OF SMP $\mathrm{N} \quad 2$ SRANDAKAN IN THE ACADEMIC YEAR OF 2013/2014." Yogyakarta State University, 2014. https://doi.org/10.1017/CBO9781107415324.004.

Walker, Joan Using Peer Tutoring to Facilitate Accessed, accessed from http://weejeelearning.com/portfoliofiles/hill_center_di/assets/resources/PeerTutorin g.pdf. Retrieved on $19^{\text {th }}$ April 2017.

Wainwright, Golden. Speed Reading Better Recalling , (Jakarta: Gramedia, 2007). 